\title{
Information and Communication Technologies for the Promotion of Open and Distance Learning in Bangladesh
}

\author{
Md. Tofazzal ISlaM* ${ }^{*}$ and Abu SADEQUe Md. SElim \\ School of Agriculture and Rural Development, Bangladesh Open University, Gazipur, Bangladesh
}

Received 24 May 2006; received in revised form 22 June 2006; accepted 22 June 2006

\begin{abstract}
Recent explosion of information and communication technologies (ICTS) in the developed countries offers tremendous opportunities for electronic delivery of course materials for open and distance learners. In spite of some socio-economic constraints, ICTs are expanding fastly in the developing countries and thus offer a new scope for the promotion of open and distance learning. Bangladesh is recently connected to the information super-highway through submarine cables, which will add a new spin in the expansion of the Internet and other ICTs. More than 10 million mobile phone users throughout the country reflect the real phenomenon of quick acceptance of the modern ICTs by the people. However, the only distance teaching public university, Bangladesh Open University (BOU) is still far behind of using modern ICTs for delivering her course materials to the distance learners. Considering the rapid expansion of computer and internet after 1998s, it is now appropriate time to consider inclusion of some interactive ICTs i.e. e-learning in delivering course materials of $\mathrm{BOU}$ and other academic institutes to promote distance education in Bangladesh. In this paper, we discuss the current situation and future prospects of ICTs in Bangladesh for the expansion of open and distance education.
\end{abstract}

Key words: ICTs, ODL, mobile learning.

\section{INTRODUCTION}

Sharing of knowledge as a factor of production, contribute significantly for the economic development and growth of a country. With the application of information and communication technologies (ICTs), dissemination and capacity to integrate and absorb human knowledge have grown immensely. The Internet and related technology facilitate the flow of information and knowledge, make it accessible to people at minimum cost, and help to establish knowledge-based society (Islam and Selim, 2006). Modern ICTs have recently been expanding rapidly in the developing countries and thus offer an excellent opportunity for effective electronic delivery of materials for open and distance learning (ODL).

Distance education is considered as an important alternative for educating mass people in Bangladesh for many socio-economic reasons (Islam and Selim, 2006). More importantly, the opportunity for higher education is extremely limited in Bangladesh, and therefore, even students, who can afford to finance their studies, it is very difficult to get admission into the universities due to limited capacity (Sadeq, 2003). Dropouts in education from primary to the university level are very high in Bangladesh, mainly due to economic and other social reasons. This scenario is well

\footnotetext{
* Corresponding author: Associate Professor, SARD, BOU. E-mail: tofazzalislam@yahoo.com

(C) 2006, School of Agriculture and Rural Development, Bangladesh Open University. All rights reserved.
} 
reflecting in very high enrollment (approx. 593 thousands students in 2006) of students at Bangladesh Open University, the first and only national distance teaching university. Recently, ICTs are rapidly expanding in Bangladesh (Islam et al., 2006) due to the deregulation of laws and policies by the Government. Bangladesh is now connected to the information super-highway through submarine cables, which will add a new spin in the expansion of the Internet and other ICTs. More than 10 million mobile phone users throughout the country reflect the real phenomenon of quick acceptance of modern ICTs by the people. Therefore, application of more electronic learning tools or ICTs may boost ODL in Bangladesh. This paper thus focuses the current status and prospects of ICTs for promoting ODL in Bangladesh.

\section{THE CONCEPT OF OPEN AND DISTANCE LEARNING}

Open and distance learning (ODL) is the most appropriate method of education for the millions of the deprived people in the less developed countries including Bangladesh. Unfortunately, however, ODL is not an effectively used method in such least developed countries (LDCs) which deserve it most. The ODL refers to a method of learning and teaching where the learner is usually separated in physical terms from the teachers and the institution that provides the education, although, in some cases, face-to-face interaction forms an important part of it. For long time, ODL has served as an alternative method for delivering education to knowledge seekers who are unable to attend traditional campus-based classes. However, its introduction to the educational settings of the developing and less developed world is quite a recent phenomenon, as is the case in Bangladesh. Distance learning is growing rapidly, not only as a supplement but also as a replacement for the traditional institutions and programs. Furthermore, distance learning is seen by many as a transformative vehicle for increasing the pace of change and reform in higher education (Ronald et al., 1998). Hence, ODL is continuously expanding in the developed world. For example, in the USA, ninety-four percent of all colleges and universities are either currently (63\%) or planning to be (31\%) engaged in distance and distributed learning (Twigg, 2001).

Bangladesh is a typical case of developing countries (LDCs), where the great majority of her population remains outside the coverage of higher education. Although late, some efforts are being made in a partial manner to offer higher education through ODL method in Bangladesh. Nevertheless, her ODL providers are less experienced in using modern ICTs who lack appropriate educational resources and know-hows. Mutual cooperation and collaboration among the ODL providers of the Asia and especially of the South Asian Countries can do a lot in the success of its provision in the country.

\section{ICT INFRASTRUCTURE OF BANGLADESH}

Bangladesh is one of the developing countries in the world with a growth rate of GDP $5-6 \%$. Like other developing countries, ICTs infrastructure in Bangladesh is weak. Computer, the important tool for communication and e-learning was first introduced to Bangladesh by the Atomic Energy Commission in 1964 (Islam, 2005). To be followed later in the 70s by its use in the financial sector, personal computers gained popularity in the early 1990s when they became more user-friendly and affordable, but the real boost came in 1998 when the Government exempted computers and ICT accessories from taxes, a move that coincided with substantial price reductions in the global market (Anonymous 2004a).

The country is recently connected to the information super-highway through submarine cables. Mobile phone is expanded very rapidly throughout the country. Thus the consumption of ICTs in Bangladesh is rapidly increasing both in public and private sectors (Anonymous 2004a). Almost all leading universities have departments of computer science and engineering. As a result, nearly 6000 new graduates are joining every year in ICT sector in the country. Bangladesh has gained approximately 2 per cent tele-density (Anonymous 2004b). Along with BTTB, many private companies such as Grameen Phone (http://www.grameenphone.com/), Telekom Malaysia, British Telecom, Aktel-TM international Ltd. (http://www.aktel.com/), City Cell (http://www.citycell.org/), Banglalink (http://www.banglalinkgsm.com/) and World Tel Bangladesh, are expanding their ICT services throughout the country. Recently, government approved VolP (Voice over Internet Protocol) in Bangladesh. It is expected that Internet, e-mail and mobile phone access will dramatically increase and expand due to the recent submarine cable connections. 


\section{MODERN ELECTRONIC ICTS USED IN OPEN AND DISTANCE LEARNING}

The explosion of electronic ICTs in the recent years offers to use some of them as tools for delivering materials for electronic learning (e-learning). e-Learning is an innovative approach for delivering electronically mediated, well-designed, learner-centered, and interactive learning environments to anyone, anyplace, anytime by utilizing the Internet and digital technologies in concern with instructional design. Applications and processes of e-learning include web-based learning, computer-based learning, virtual classrooms, and digital collaboration, where contents are delivered via the Internet, intranet/extranet, audio and/or video tapes, TV and radio broadcasts, CD-ROM etc. The issue of e-learning has been received an increasing level of interest in recent years for the promotion of open and distance learning (ODL), and it is now a multi-billion dollar activity worldwide. Some important ICTs related to e-learning are briefly discussed below.

CBT (computer based training) - Generally CBT and e-learning are synonymous, but CBT is the older term, dating from the 1980s. CBT is a general term that relates to all training that is delivered with the assistance of a computer. Deliver of CBT can be via CD, the Internet, or shared files on a network.

Internet - The Internet, or simply the Net, is the publicly accessible worldwide system of interconnected computer networks that transmit data by packet switching using a standardized Internet Protocol (IP). It is made up of thousands of smaller commercial, academic, domestic, and government networks. It carries various information and services, such as electronic mail, online chat, and the interlinked Web pages and other documents of the World Wide Web. Contrary to some common usage, the Internet and the World Wide Web are not synonymous: the Internet is a collection of interconnected computer networks, linked by copper wires, fiber-optic cables etc.; the Web is a collection of interconnected documents, linked by hyperlinks and uniform resource locators (URLs), and is accessible using the Internet.

WWW (World Wide Web) - Through keyword-driven Internet research using search engines like Google, millions worldwide have easy, instant access to a vast and diverse amount of online information. Compared to encyclopedias and traditional libraries, the World Wide Web has enabled a sudden and extreme decentralization of information and data.

Videobook - A book performed in video format, or a video structured similarly to a book used chiefly in teaching.

VolP - VoIP stands for Voice over IP, where IP refers to the Internet Protocol that underlies all Internet communication. This phenomenon began as an optional two-way voice extension to some of the Instant Messaging systems that took off around the turn of the millennium.

WBT (Web-based Training) - Training that is delivered with the assistance of the Internet.

LMS (Learning Management System) - A system for management and tracking of the involvement of participants with specific content, usually with the assistance of database. Typically the system tracks who is scheduled to participate in specific training programs, who has begun the program, who has completed the trainings, and what were the participants' test scores.

LCMS (Learning Content Management System) - A system for collaborative delovement of elearing content with inbuilt resources sharing and project management processes.

Content - What is taught in a course, class, or lesson. The training objectives are often a list of the content of a course.

Synchronous e-learning - Computer-assisted training where the instructor and participants are involved in the course, class or lesson at the same time (synchronized). Web conferencing is an example of synchronous e-learning. Participants can log on with a trainer and interact with participants at multiple facilities or locations. Using LCD projectors and conference telephones, the audience of a web conference can be increased to include many staff at any location.

Asynchronous e-learning - Computer-assisted training where the instructor and participants are involved in the course, class or lesson at different times (not sychronized, or asynchronous). Examples include job aids and programs on a shared drive, web-based training (WBT), electronic 
bulletin boards, blogs, and email listservs. Asynchronous methods allow participants to access training materials 24/7, even when other students and/or the instructor are not present.

Electronic bulletin board-A method of communication where topics or questions are posted to a website and participants can respond.

Blog - Web log. Similar to an electronic bulletin board, except that only one individual or group can create the initial post and participants can only respond to the post.

Listserve - An electronic mailing list. Members send email to the list, which the list service then mails to all members individually. Members can then read and respond (called a post), or email the member directly.

ASP (Application service provider) - Some LCMS products are available in a format that is Internet-based or network-based. This means that there is little or nosoftware to install on the local computer to deliver and track the training. The information is tracked totally at the remote or server location. Service is generally subscription-based, and password protected.

Educational technology - The use of technology to improve education. It is a systematic, iterative process for designing instruction or training used to improve performance. Educational technology is sometimes also known as instructional technology or learning technology.

Educational animation - Depictions that support the learning of dynamic content by providing direct information about how changes occur over time.

Page Turner - CBT which requires the participant to simply read and move from screen to screen to turn pages and read some more.

Courseware - Software that is designed for an educational program.

NLT (Notional Learning Time, or Seat time) - It is the time taken for completing an e-learning course. This is an approximation of the amount of time @80-90 percentile of the target audience will take to complete the course.

PDAs (Personal digital assistants) - PDAs are handheld devices that were originally designed as personal organizers, but became much more versatile over the years. PDA is popularly known as walking computer. A basic PDA usually includes date book, address book, task list, memo pad, clock, and calculator software. Newer PDAs also have both color screens and audio capabilities, enabling them to be used as mobile phones, web browsers or media players. Many PDAs can access the Internet, intranets or extranets via Wi-Fi, or Wireless Wide-Area Networks (WWANs).

\section{MOBILE LEARNING}

Mobile learning or m-learning is a development from e-learning which for its part originates from dlearning (distance learning). The rapid growth of information and communication technologies (ICTs) makes it possible to develop new forms of this education. Today's students knowledge of mobile devices makes the entrance of mobile learning (m-learning) possible. m-Learning is the term given to the delivery of training by means of mobile devices such as PDAs, mobile phone and digital audio players. m-Learners are seeking "just in time, just for me" lessons in small, manageable formats that they can undertake when it suits them.

$\mathrm{m}$-Learning also provides teaching opportunities to the instructor (McDonough, 2006). They can utilize current software to test students and receive immediate feedback, help student prepare for the workplace, personalize learning experiences and take advantage of just-in-time" learning. Who would have thought that the simple birth of a calculator in 1974 would turn into a device that would imitate a computer but fit in the palm of your hand? While it is amazing to think the future of technology is unimagined and in many ways unimaginable, students and teachers will be doing as new technology continues to revolutionize the way people learn.

\section{DIFFERENCES BETWEEN M-LEARNING AND E-LEARNING}

In general, mobile learning can be viewed as any form of teaching or studying that happens when a learner is interacting through a mobile device. Nevertheless here we try to transfer the services provided by an e-learning platform (enumerated previously) into the mobile context. We can easily 
see that there are services that need to be adapted to fulfill the limitations of certain devices, there are other services that are infeasible to transfer, but also new services appear, provoked by the mobility.

The connectivity is one of the main differences if we compare a mobile device with the PC (the usual medium for delivering e-learning). Nowadays mobile devices might be connected to 'The Net' via many technologies - WAP, GPRS, UMTS, Bluetooth, WiFi, etc. Although it is predictable that in the future the 'always on' will be wide spread still it is not the case. Mobile devices often have periods of disconnection, either intentionally (when the connection is too expensive) or not (when no infrastructure is provided).

Devices' hardware and software characteristics have a big impact on what content is possible and meaningful to be delivered. Usually the web content is designed for desktop PCs, thus unpleasant and even rarely useful from a small-screened device. Nowadays, mobile phones are rapidly becoming increasingly powerful (both from hardware and software point of view) however their screens will remain comparatively small. Often also the navigation is hard. Equipped with a small phone-style keyboard or a touch-screen (for the PDAs) the users might loose more time in searching where on the page the information they need is than in reading it. We can imagine alternative ways of navigation, for example voice commands. The memory available on a mobile device is also relatively small. It is possible to use extension packs on some devices like PDAs, which reduces some of the restrictions.

\section{ROLE OF BANGLADESH OPEN UNIVERSITY IN THE PROMOTION OF DISTANCE EDUCATION}

Bangladesh Open University (BOU), a public sector university, has emerged as the first University in Bangladesh to introduce higher education through distance mode. BOU is providing higher education and professional training in wide areas such as agriculture, business, education, arts, science and technology as well as basic education at secondary and higher secondary levels. It introduces several formal academic programs from Certificate to Masters levels under seven academic schools. Year-wise enrollment of BOU students is shown in Fig. 1.

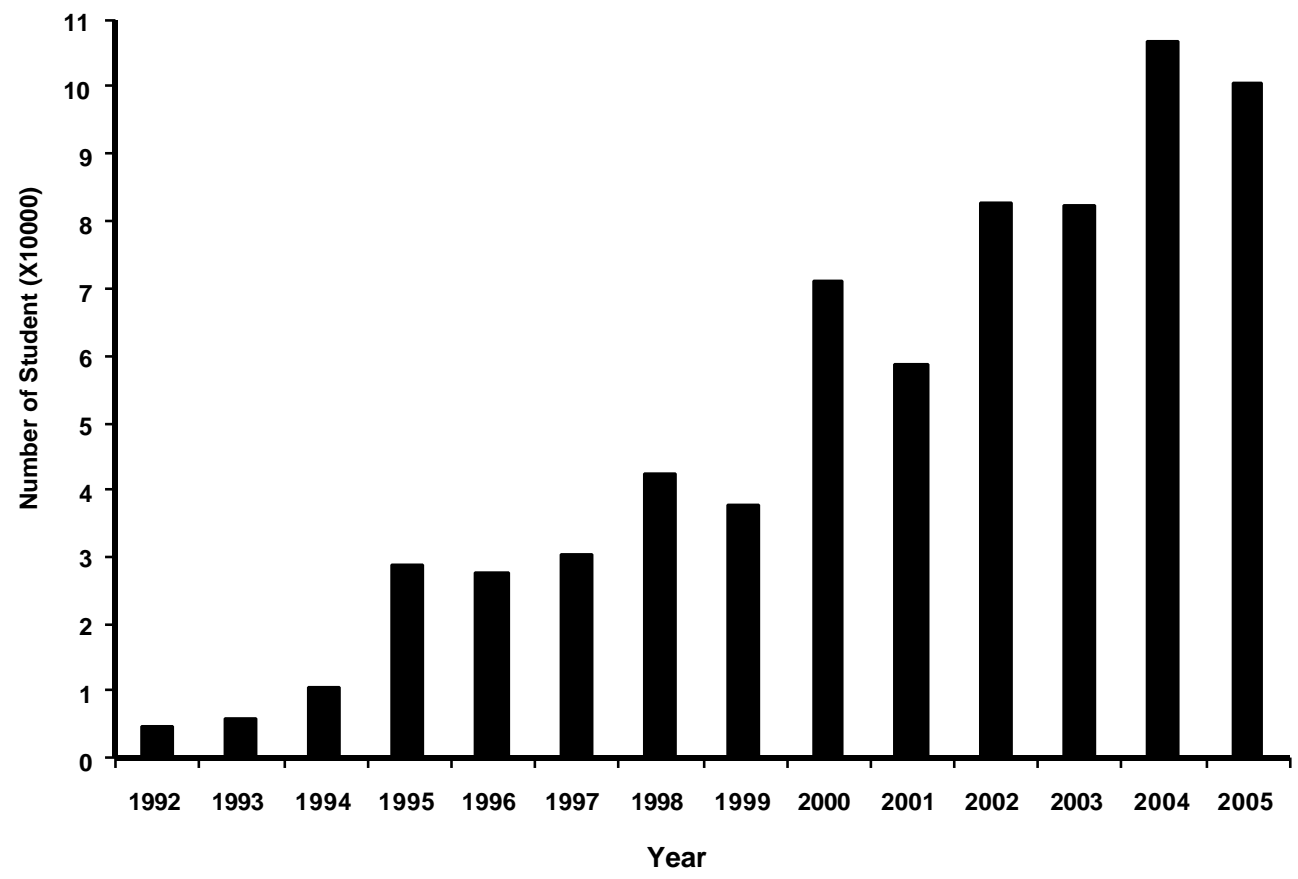

Fig. 1. Year-wise students enrollment in different academic programmes of BOU

Note: Total enrolled students upto $07 / 03 / 2006=708,500$; Total no. of certificate and degree awarded = 114,659; Curruent students $=593,841$; Source: Student Support Service (SSS) Division, BOU. 
Considering the importance of life-long learning, BOU broadcasts many non-formal programs in the field of agriculture, health and nutrition, environment, livestock and poultry, pisciculture, public laws, ethics, family planning etc. through national TV and radio-broadcast (Anonymous, 2002).

As a distinct mode of imparting education, Bangladesh Open University relies heavily on print materials, electronic media like radio-television and audio-video cassettes, and face to face tutorial services (Islam et al., 2005). The use of these techniques helps BOU to take its academic programs to the door-steps of people far and wide. It makes room for in-house education. Considering the rapid expansion of ICT in the country, BOU may introduce more electronic media like mobile phone, CD-ROM, e-mail, open courseware, internet for its advanced learners. It is necessary to survey of student access in common ICTs to make a pilot project for introducing interactive e-learning system for the BOU students.

BOU student enrollment in different programs is dramatically increasing since its operation in 1995 (Fig. 2). The advantages of BOU education is well reflected in the annual report 2004-2005 of the Bangladesh University Grants Commission (Table 1). It is revealed that BOU education is superior to all other public universities in Bangladesh in terms of cost per student, male-female and teacherstudents ratios, and income from the own source of the total budget (Table 1). The students enrollment from different programs (Fig. 2) (Islam et al., 2005), suggest that BOU certainly exists as one of the mega-universities in future and will take the responsibility for educating the mass people in Bangladesh (Islam et al., 2006), If it is possible to improve the socio-economic conditions and ICTs infrastructure of the country, introduction of interactive e-learning could boost ODL and directly contribute to the development of Bangladesh.

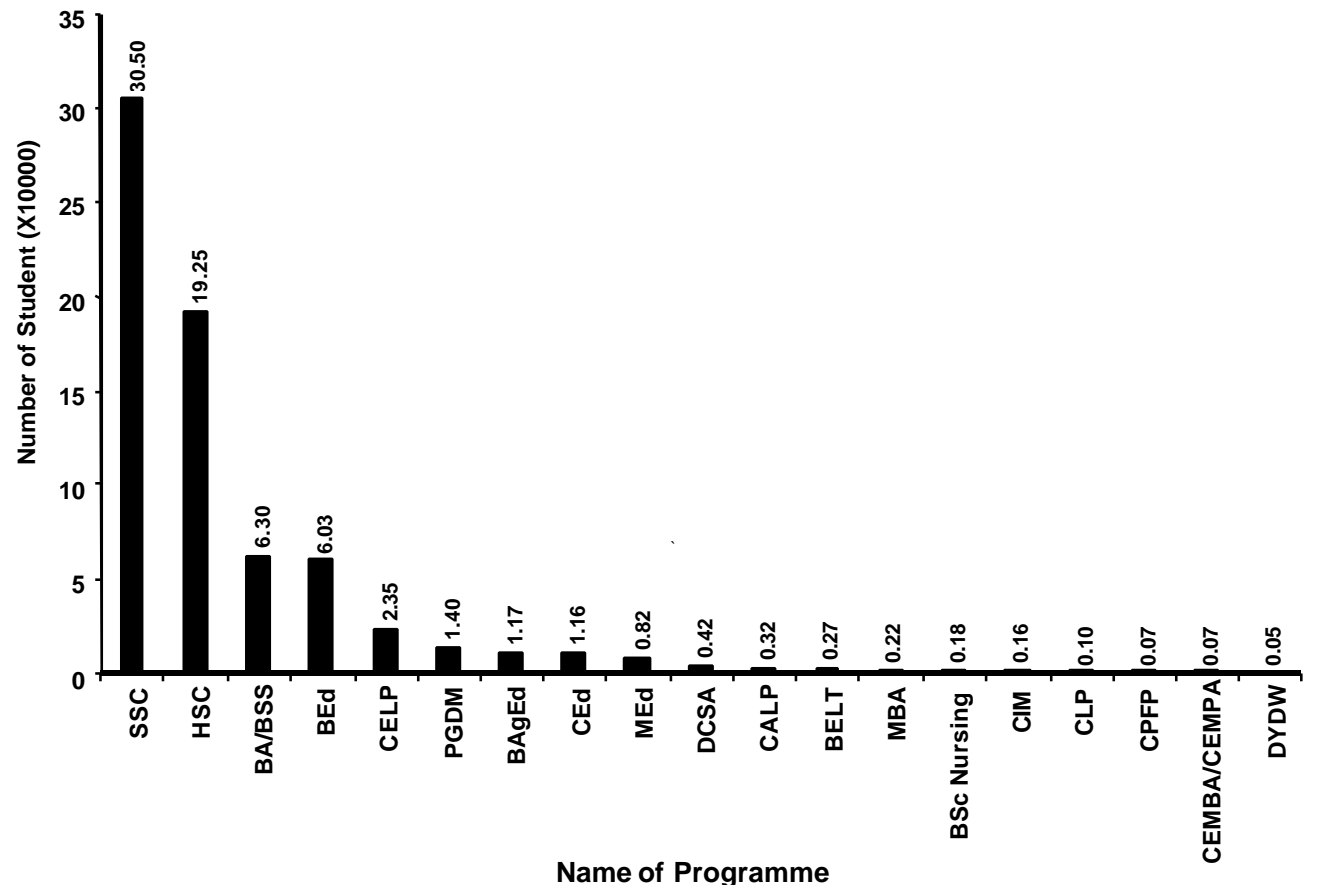

Fig. 2. Students enrollment in different academic programmes of BOU in 2005

Note: SSC = Secondary School Certificate, HSC = Higher Secondary Certificate, BA/BSS $=$ Bachelor of Arts/Bachelor of Social Science; BEd= Bachelor of Education; CELP = Certificate in English Language Proficiency; PGDM= Post Graduate Diploma in Management; BAgEd= Bachelor of Agricultural Education; CEd=Certificate in Education; MEd= Masters in Education; DCSA = Diploma in Computer Science and Application; CALP = Certificate in Arabic Language Proficiency; BELT = Bachelor in English Language Teaching.; MBA = Masters of Business Administration; BSc Nursing = Bachelor of Science in Nursing; $\mathrm{CIM}=$ Certificate in Management; $\mathrm{CLP}=$ Certificate in Livestock and Poultry; CPFP = Certificate in Pisciculture and Fish Processing; CEMBA /CEMPA = Commonwealth Executive Masters of Business Administration/ Commonwealth Executive Masters of Public Administration; DYDW = Diploma in Youth in Development Work. 
Table 1. Some important statistics of major public universities in Bangladesh (2004-05)

\begin{tabular}{|c|c|c|c|c|c|}
\hline Name of the University & $\begin{array}{l}\text { Number of } \\
\text { Students } \\
(\times 1000)\end{array}$ & $\begin{array}{c}\text { Teacher } \\
\text { Students } \\
\text { Ratio }\end{array}$ & $\begin{array}{c}\text { Male-Female } \\
\text { Ratio of } \\
\text { Students }\end{array}$ & $\begin{array}{c}\text { Cost/ } \\
\text { Students/ } \\
\text { Year } \\
(T k \times 1000)\end{array}$ & $\begin{array}{c}\text { Income from } \\
\text { own source } \\
\text { of total } \\
\text { budget }(\%)^{*}\end{array}$ \\
\hline Dhaka University & 24 & $1: 16$ & $2: 1$ & 37.2 & 10 \\
\hline Rajshahi University & 27 & $1: 29$ & $3: 1$ & 21.9 & 5 \\
\hline Bangladesh Agricultural University & 04 & $1: 8$ & $3.5: 1$ & 121.0 & 4 \\
\hline $\begin{array}{l}\text { Bangladesh University of Engineering } \\
\text { and Technology }\end{array}$ & 08 & $1: 16$ & $5.5: 1$ & 45.8 & 7 \\
\hline University of Chittagong & 15 & $1: 23$ & $3: 1$ & 29.2 & 7 \\
\hline Jahangirnagar University & 07 & $1: 18$ & $2: 1$ & 42.0 & 8 \\
\hline $\begin{array}{l}\text { Shahjalal University of Science and } \\
\text { Technology }\end{array}$ & 06 & $1: 17$ & $4.5: 1$ & 15.2 & 13 \\
\hline Khulna University & 03 & $1: 12$ & $4: 1$ & 3.4 & 6 \\
\hline Bangladesh Open University & 437 & $1: 4807$ & $1.4: 1$ & 0.8 & 51.0 \\
\hline $\begin{array}{l}\text { Chittagong University of Engineering } \\
\text { and Technology }\end{array}$ & 1.8 & $1: 21$ & $12: 1$ & 30.3 & 8.0 \\
\hline $\begin{array}{l}\text { Rajshahi University of Engineering and } \\
\text { Technology }\end{array}$ & 1.1 & $1: 11$ & $8: 1$ & 50.2 & 6.0 \\
\hline $\begin{array}{l}\text { Khulna University of Engineering and } \\
\text { Technology }\end{array}$ & 2.0 & $1: 25$ & $8.5: 1$ & 46.0 & 6.0 \\
\hline $\begin{array}{l}\text { Dhaka University of Engineering and } \\
\text { Technology }\end{array}$ & 1.4 & $1: 13$ & $16: 1$ & 44.7 & 7.0 \\
\hline Islamic University & 08 & $1: 29$ & $4.3: 1$ & 17.6 & 15.0 \\
\hline $\begin{array}{l}\text { Bangabandhu Sheikh Mujibur Rahman } \\
\text { Agricultural University }\end{array}$ & 0.3 & $1: 6$ & $3: 1$ & 122.1 & 9.0 \\
\hline $\begin{array}{l}\text { Bangabandhu Sheikh Mujib Medical } \\
\text { University }\end{array}$ & 0.7 & $1: 3$ & $2.3: 1$ & 139.2 & 3.0 \\
\hline $\begin{array}{l}\text { Hajee Mohammad Danesh University } \\
\text { of Science and Technology }\end{array}$ & 0.7 & $1: 12$ & $3.4: 1$ & 43.8 & 4.0 \\
\hline $\begin{array}{l}\text { Maulana Bhasani University of } \\
\text { Science and Technology }\end{array}$ & 0.2 & $1: 17$ & $3: 1$ & 144.0 & 24.0 \\
\hline Sher-e-Bangla Agricultural University & 1.3 & $1: 15$ & $3.3: 1$ & 37.0 & 8.0 \\
\hline $\begin{array}{l}\text { Patuakhali University of Science and } \\
\text { Technology }\end{array}$ & 0.6 & $1: 13$ & $4.4: 1$ & 106.0 & 4.0 \\
\hline National University & 416 & $1: 7$ & $1.7: 1$ & 1.12 & - \\
\hline
\end{tabular}

*Approximate; Source: Adapted from the Annual Report of Bangladesh University Grants Commission 2004-05.

\section{PROSPECTS FOR USING ICTS IN E-LEARNING IN BANGLADESH}

The ICTs have several advantages in promoting distance and open learning. There are many examples of huge public participation in online activities in Bangladesh such as online publication of the results of Secondary School Certificate (SSC) examination, TeleTalk SIM application, DV lottery and so on. Interactive TV introduced by the private TV channels has been earning popularity day by day. Online banking and uses of Internet at home, office and in the cyber cafes have been expanding. Most of the daily newspapers are publishing in both online and print formats. Current mobile phone users in the country are exceeded 10 million. Surprisingly, the use of modern electronic ICTs in open and distance learning is still limited. Some of the important aspects of elearning are briefly noted below:

1) Internet connections are very few, this model has high potential to attract large crowd, which helps to entrepreneur to be a part of e-learning.

2) High quality Internet infrastructure and networking will help to deliver high quality courses. 
3) Computers with high internet infrastructure will help to reduce the overheads as there won't be any recruitment, training, and up-gradation of faculties.

4) Due to socio-economic conditions, large number of students still avoids schools; elearning may involve them in studies.

5) E-learning provides the courses round the clock i.e. 7 days a week and 24 hours a day, which further attracts working people, students and even individuals.

6) The courses provided in this model are having wide variety of courses based on IT and non-IT topics, which is an additional benefit to attract the large crowd from all the background.

7) The learners need not pay any additional amount for any up-gradation on the courses once being a member. This saves learners time and cost.

\section{CONCLUSION}

Over the last few decades, many countries in the Asia have made remarkable achievement in the socio-economic development exploiting full advantages of ICTs in their national development policy framework. Bangladesh is currently connected to the information super-highway through submarine cables, which will add a new spin in the expansion of Internet and other electronic communications. More than 10 million mobile phone users throughout the country reflect the real phenomenon of quick acceptance of modern ICTs by the people. Private TV channels have also started interactive live non-formal educational programs for increasing public awareness in health and other affairs. But the full potentials of ICTs infrastructure are yet to be exploited by BOU and other institutes that are commited to the promotion of open and distance learning. It is expected that the current improvement of ICTs infrastructure of Bangladesh may promote open and distance learning for educating mass of her people.

\section{LITERATURE CITED}

Anonymous. 2004a. Bangladesh Software Industry Survey Report, Japan External Trade Organization, Dhaka.

Anonymous. 2004b. USTDA South Asia Communications Infrastructure Conference, New Delhi, April 21-23, India.

Anonymous. 2002. Project Performance Audit Report on Bangladesh Open University Project in Bangladesh (Loan 1173-BAN [SF].

Bangladesh Open University. 1997. Contact for Consulting Services for Training Packages, BOU, Gazipur. pp. 20-22.

Islam, M. T. and Selim, A. S. M. 2006. Current status and prospects for e-learning in the promotion of distance education in Bangladesh. Turkish Online Journal of Distance Education 7(1), article no. 11.

Islam, M. T., Rahman, M. M. and Rahman, K. M. R. 2006. Quality and processes of Bangladesh Open University course materials development. Turkish Online Journal of Distance Education 7, 130-138.

Islam, M. T. 2005. 08 July 2005. E-learning and human resource development. In "The Bangladesh Observer", Dhaka. p. 4.

Islam, M. T., Selim A. S. M. and Rahman, M. M. 2005. Promotion of distance education through digital technology. Information Technology Journal 4, 454-488.

McDonough, K. 2006. PDAs: Revolutionizing the way we learn and teach. Turkish Online Journal of Distance Education 7, 153-159.

Phipps, R. A., Wellman, J. V. and Merisotis, J. P. 1998. Assuring Quality in Distance Learning. A report prepared for the Council for Higher Education Accreditation by The Institute for Higher Education Policy, Washington DC.

Sadeq, A. M. 2003. Cooperation and collaboration for ODE: The case of Bangladesh. Paper presented in $17^{\text {th }}$ AAOU Annual Conference, Held on Thailand, 12-14 November 2003.

Twigg, C. A. 2001. "Quality Assurance for Whom? Providers and Consumers in Today's Distributed Learning Environment", The New Learning and Technology Program 2001. New York Center for Academic Transformation, Rensselaer Polytechnic Institute. 